\title{
THE INTERNATIONAL CRIMINAL COURT: ISSUES FOR CONSIDERATION BY THE UNITED STATES SENATE
}

\author{
PATRICIA MCNERNEY*
}

\section{INTRODUCTION}

Staff in the Senate like to joke that there are one hundred Secretaries of State, so I start by noting that my comments do not presume to be on behalf of any particular senator. Rather, this comment will simply outline some of the problems as I see them, and some actions that have been taken to date by Congress.

The Senate takes seriously its constitutional role of advice and consent to the ratification of treaties. While counsel to the Foreign Relations Committee, I worked on numerous treaties during the past five years. The Committee gives its advice and consent to an average of about fifty treaties a Congress. These treaties relate to such mundane topics as maritime borders and migratory birds, and to topics such as bilateral extradition, tax, and investment.

Two of the most worrisome and controversial multilateral U.N. treaty negotiations in my portfolio included the Kyoto Protocol to the Climate Change Convention ${ }^{1}$ and the Rome Statute of the International Criminal Court (the "ICC"). ${ }^{2}$ Although the United States has signed one of the two treaties, neither has been submitted to the United States Senate for its advice and consent. Undoubtedly both as currently drafted would fail to get the two-thirds support necessary for ratification.

There is some comparison to be made between the two treaties. Although the subject matters are very different, as a matter of treaty law, both treaties represent a growing trend in multilateral treaty negotiations. The treaties erode aspects of sovereignty by placing international legal obligations more directly on the citizens of nations-whether in their individual or corporate capacityrather than governments. For example, the Rome Treaty would permit trial of individuals without a nation's consent. Such trials could result in imprisonment, revoking the most fundamental right of a democratic society, that of liberty.

Copyright (C) 2001 by Patricia McNerney

This article is also available at http://www.law.duke.edu/journals/64LCPMcNerney.

* General Counsel, Senate Select Committee on Intelligence; formerly Counsel, U.S. Senate Committee on Foreign Relations.

1. U.N. Doc. FCCC/CP/1997/7/Add. 1 (Mar. 18, 1998).

2. U.N. Doc. A/CONF.183/9 (July 17, 1998). 
The Kyoto Protocol creates and grants value to a new property right, carbon emissions, and establishes an institution called the Clean Development Mechanism that would regulate the investment of businesses seeking to obtain credit for environmentally sound technology used abroad.

The nearly simultaneous negotiation of both these treaties suggests the U.S. Administration is increasingly comfortable with a more robust legislative role for U.N. institutions. Therein lies the tension between the Senate and the Executive Branch in the debate on the ICC Treaty.

Ironically, these multilateral treaties are negotiated far away from the seats of government. For example, when a U.S. Treasury team negotiates a bilateral tax treaty, they sit down with key government officials in both of their capitals. The United States generally has a bottom-line that must be acceptable to both parties before it is willing to initiate treaty discussions. Once accepted, the negotiations begin and enable a fair amount of information sharing, which serves to strengthen domestic institutions, particularly in developing countries, and ensure that key U.S. concerns form the basis of the treaty.

In large multilateral treaty negotiation settings, countries often cannot afford to send delegations and instead depend on delegates of non-governmental organizations ("NGOs") to represent them, some of whom may have their own agenda at these negotiations that may be inconsistent with the interests of the country they are representing. In Rome, I witnessed one instance in which an NGO was accredited by a small nation to sit in the nation's chair and speak on behalf of that country. Rather than strengthening domestic institutions, such negotiations stretch budgets of small nations and inevitably lead to new and costly international institutions located in distant cities.

Today, the United States pays assessed contributions to more than fifty international organizations and contributes on a somewhat voluntary basis to some thirty others. It is difficult-as some would have us do-to consider the ICC outside the context of this burgeoning group of international organizations. Assessed costs of international organizations are part of the State Department's operating budget, and now account for more than twenty-five percent of the President's request to fund State Department activities, or about $\$ 1.2$ billion. Often budgets are set by these organizations without the consent of the United States. Hundreds of millions of dollars support other international organizations through U.S. foreign aid appropriations for voluntary activities and by the Pentagon for peace and security.

So, with some of these concerns as a context, this essay discusses some of the fundamental problems that many in Congress have identified with the proposed International Criminal Court.

\section{SOVEREIGNTY}

The key over-arching concern regarding the ICC Treaty is its impact on the rule of law of sovereign nations. Several key aspects of this concern follow. 


\section{A. Legislating International Law}

As a matter of international law, the ICC Treaty breaks new ground in how the international community comes to agree upon what is or is not international law. Far from taking a customary law approach, this Treaty attempts to legislate international law. One need look no further than the fact the Treaty is called the "Rome Statute of the International Criminal Court" to discover the intent of negotiators to legislate. I am not certain whether it is the first treaty to be given the title "statute," but it is certainly telling as to what negotiators had in mind.

The Treaty legislates a number of crimes within the four generally recognized international humanitarian law crimes of genocide, crimes against humanity, war crimes, and aggression (which negotiators left to be defined at a later date). The Treaty fleshes out elements that would constitute genocide, crimes against humanity, and war crimes in Articles 6-8, in some instances drawing from other treaties (that may or may not be self-executing treaties under U.S. law), but, in many instances, simply creating new elements of criminal behavior. For example, Article 21 of the Convention permits the application of general rules and principles of international law but makes no reference to legitimate reservations or understandings that may have served as the basis for acceptance of a treaty by a government.

For an elected senator or representative to the U.S. Congress, the problem with this scenario is clear. Most members rightly feel that they, not the Executive Branch, and not representatives of other nations, were elected to write the laws that bind U.S. citizens, and that U.S. courts should interpret such laws. The Rome Treaty, which contains a "no reservations" clause, effectively means the treaty is "take it or leave it" and would prohibit the Senate from placing its stamp on the tribunal, and determining the kinds of laws that will apply to U.S. citizens acting within U.S. jurisdiction.

\section{B. Universal Jurisdiction}

The greatest departure from accepted treaty interpretation made by negotiators in Rome is the assertion that the Treaty is binding on all persons, regardless of whether their governments have ratified the Treaty. Article 12 of the ICC Treaty, regarding preconditions to the exercise of jurisdiction, presumes to apply to the United States even without ratification pursuant to Article II, section 2 of the U.S. Constitution. Such a treaty formulation in fact undermines the rule of law and creates a dangerous precedent for future treatymaking. Effective acquiescence procedures are a tenet of treaty-making.

This formulation effectively places the United Nations in the role of defining criminal conduct for all persons, including U.S. senior elected officials and military personnel. This approach is diametrically opposite to current trends in the United States that return legislative authority to localities, where decisionmakers are more accountable. 
Thus, if an act that is defined as a crime by the Rome Treaty were to take place in Bosnia but the President of the United States ordered the act from Washington D.C., the ICC could claim jurisdiction to prosecute. (Of course, the likelihood of the court getting jurisdiction over U.S. leaders is another matter.) Or for that matter, if a crime covered by the Treaty were carried out against an American citizen outside the United States, there might be a greater effort made to bring a case involving a U.S. servicemember before the international tribunal rather than a U.S. court.

In fact, because of this formulation, the Treaty may have the unintended consequence of limiting U.S. involvement around the world. Unless agreements are reached in status of forces agreements and other fora that would prohibit prosecution of U.S. citizens undertaking official duties, the decision to take action or locate troops in certain locations may be affected.

\section{Impediment to Foreign Policy}

Perhaps one of the larger fallacies asserted with regard to the ICC relates to its effect on judicial action. The argument is that the court will complement sovereignty, and because it gives the court the maximum degree of independence, it will depoliticize international justice. At the Rome negotiations, however, the senior European Union commissioner, Emma Bonino, made a revealing comment. She asserted that "foreign policy may well be the last vanity of nations," ${ }^{3}$ apparently presuming that the foreign policy of sovereign nations is an impediment to international justice.

Such assertions seem to highlight one of the essential problems with those supporting the ICC: They assume judicial activity functions separately from other institutions and processes. In fact, the "independent judiciary" often works in concert with other legislative and executive bodies. In the United States, of course, we have a system founded on three co-equal branches of government at the federal level. Through an appointment process, and the ability to enact new legislation or amend the Constitution, the judiciary is accountable to its citizens through their elected representatives.

A recent example demonstrates that this is no different at the international level. In February 1999, in an effort to make Moammar Qadhafi honor his commitment to turn over the two individuals alleged to have carried out the bombing of Pan Am 103 over Scotland, Kofi Annan, Secretary General of the United Nations, sent a secret letter to Qadhafi with certain assurances. ${ }^{4} \mathrm{Al}-$ though that letter was not made public, press reports suggest those assurances included assertions that any discussion of the Government of Libya's role in the bombings, including Qadhafi's role, would be off limits. ${ }^{5}$ As later events indicated, Annan also promised a relaxation of multilateral sanctions imposed on

3. Filibustering Tactics Stall Negotiations, 13 TERRA VIVA, Rome, July 1, 1998.

4. See U.N. Chief Gives Assurances to Libya in Lockerbie Trial, DEUTSCHE-PRESSE-AGENTUR, Feb. 17, 1999.

5. See Daily Press Briefing, Dep't of State, Feb. 17, 1999. 
Libya in return for handing the two individuals over to the Scottish Court, which will sit in The Netherlands. ${ }^{6}$

The Libya case demonstrates that foreign policy can never be disassociated from any judicial action that crosses sovereign borders. What it does do, however, is place unaccountable bureaucrats more directly in a position to influence foreign policy of individual nations. The elected officials who are accountable to the families of the victims of Pan Am 103 are thereby less responsible for ensuring a full accounting of the crime.

Another case with larger foreign policy implications is the imminent establishment of a Cambodian War Crimes Tribunal once the Cambodian Parliament approves the agreement reached between the Cambodian government and the United Nations to establish the tribunal. ${ }^{7}$ Most advocates of a tribunal to address the Khmer Rouge's atrocities would establish a tribunal without any possibility of addressing current actions of the Hun Sen regime, which currently is in power in Cambodia. The Hun Sen regime is composed almost entirely of former Khmer Rouge members. Although it is certainly understandable that those who suffered under the Khmer Rouge want to bring perpetrators of the crimes to justice, it is difficult to comprehend how such a tribunal will provide that sense of justice when the current regime continues to violate fundamental human rights. ${ }^{8}$

Both these examples yield serious questions that must be considered in a larger foreign policy context. A court that avoids wresting with the tough questions and thereby enables current perpetrators of abuses to avoid prosecution in the name of bringing justice only when criminals are out of power seems to be a hollow kind of international justice.

\section{Unaccountable Prosecutors}

Another key problem with the ICC Treaty is its grant of broad authority to the ICC's prosecutor. Instead of vesting the Security Council with the sole power to refer a case, the Treaty waters down the veto power of the Council. Under the Treaty, any case proposed by the prosecutor and approved by the judges, will proceed unless there is full support by the Permanent Five to stop a case.' Many in Congress and senior Pentagon officials advocated instead a Security Council "screen" for the referral of cases to a permanent tribunal, so that all cases would be commenced by a vote of the Security Council as has been the case for the ad hoc tribunals for Rwanda and the Former Republic of Yugoslavia.

6. See U.N. Chief Gives Assurances, supra note 4.

7. See UN Allows Cambodians to Take Part in a Trial of Khmer Rouge, NY TIMES, May 25, 2000, at 9 .

8. See U.N. Faces Tough Negotiations over Khmer Rouge Trial, AgEnCE FrAnCE Presse, Aug. 27, 1999.

9. See Rome Statute of the International Criminal Court, U.N. Doc. A/CoNF. 183/9, art. 16 (July 17, 1998). 
Without this protection, the Treaty increases the possibility of an overzealous and unaccountable prosecutor. Moreover, under the Treaty, removal of the prosecutor may occur only in the case of serious misconduct or serious breach of duty. The reality is that a roving prosecutor will not be restrained easily. She or he will be limited only by a pretrial chamber that determines whether the prosecutor may go forward and issues orders and warrants at the request of the prosecutor.

Whether such a construct would provide adequate protection from improper prosecution is questionable. Before the Independent Counsel Statute in the United States expired quietly on June 30, 1999, many questioned the independence of the independent counsel, despite the check of the Attorney General as well as the three judge panel needed for the counsel to proceed with an inquiry. There is some irony in the fact that many of the same voices criticizing the independent counsel authority now support the creation of an international court-accountable to no single government—based on the same, if not a lesser, safeguard structure.

\section{E. Judges from Terrorist and Repressive Regimes}

Despite the stated goal of increasing the rule of law, the criteria for judges is broad and not rigorous. A judge from any country listed by the United States as a terrorist regime, or from any country that does not have a democratically elected government or a functioning judicial system may sit in judgment of U.S. citizens. There is no prohibition on a judge from Iraq or Iran, or any of the other countries on the U.S. terrorist list. There is no prohibition on a judge from China, where the United States recently proposed a resolution before the U.N. Human Rights Commission to condemn China's repressive human rights practices. Certainly, there is some irony in failing to develop criteria that limits the ability of judges from repressive or non-democratic societies to be empaneled on the ICC. In fact, in 1994, Congress prohibited the United States from participating in any international criminal court in which citizens from vague nations were empaneled to sit in judgment of American citizens. ${ }^{10}$

\section{F. Current Extradition Practices}

The United States is party to more than 110 bilateral extradition treaties. It is the practice of the United States to extradite its nationals to stand trial in foreign jurisdictions. Before the United States enters into an extradition agreement, it must first be determined whether a potential treaty partner has a judicial system that provides due process and humane treatment of detainees. For good reason, the United States does not have extradition relationships with all nations.

During the 105th Congress, the Senate gave its advice and consent to eighteen extradition treaties. Of those eighteen treaties, Austria, Cyprus, France,

10. See Foreign Relations Authorization Act, Pub. L. No. 103-236, 108 Stat 382518 (1994). 
Luxembourg, and Poland all refused to obligate themselves to extradite their nationals. During that same period, each of these countries signed the Rome Statute and made grandiose statements regarding international justice. Many of those same countries are also parties to the Hague Convention on the Civil Aspects of International Child Abduction. ${ }^{11}$ During the 105th Congress, the Foreign Relations Committee held a hearing at which the Attorney General and a number of affected parents testified. ${ }^{12}$ Many of the same countries in Europeespecially Sweden, Austria, and Germany - that advocated for the creation of a criminal court refuse to return wrongfully retained children held in their countries, which is explicitly required by the Hague Treaty. ${ }^{13}$

These two examples highlight the reality that despite the high level of rhetoric aimed at the United States during negotiation of the ICC Treaty, and calls for international justice, none of these voices have been raised in support of eliminating laws that enable criminals to hide behind legal impediments to extradition. The failure of countries to facilitate extradition of their nationals results in law enforcement agencies being unable to muster the legal cost of trying a case in a foreign court and deciding not to pursue such cases, or, in the case of child abduction, permits countries like Germany and Austria to deny parents the right to even visit their children. Efforts to implement these basic treaty commitments could go a long way to bringing perpetrators of crimes to justice.

These impediments also raise questions regarding some basic hurdles to full implementation of treaty commitments under the Rome Treaty. Current practice would suggest that the signatories to the Treaty are far from prepared to implement the Treaty, and leaves serious doubt as to their willingness to impose rigorous standards when their own citizens are implicated.

III

\section{PoliticizATION OF JUSTICE}

In addition to this activist legal agenda, the Rome Treaty sets up a new forum for disputes between nations. However, in this case, individuals, not governments, become the pawns of such disputes. The potential for U.S. servicemen and women to become a means to attack the United States is simply unacceptable to many senators.

If current examples are any guide, we can learn much from the International Court of Justice. Three of the twenty-three cases on the court's docket are directed against the United States. Two of the cases have been brought by Libya and Iran for U.S. military operations, and one has been brought by Germany to influence U.S. domestic law regarding the death penalty. ${ }^{14}$ It would be naive to

11. For the status of the treaty, see <www.un.org/law/icc/statute/status.htm>, and for the status of the Hague Convention, see $<\mathrm{http}: / /$ www.hcch.net/e/status/stat28e.html $>$.

12. See S. Hrg. 105-845 (Oct. 1, 1998).

13. See Hague Convention on the Civil Aspects of International Child Abduction, Oct. 25, 1980, T.I.A.S. No. 11670 , Art. 7.

14. See <http://www.icj-cij.org/icjwww/idocket.htm>. 
think similar cases would not be attempted against Americans in an international criminal tribunal. In Libya, for example, there are indictments against President Reagan, his senior foreign policy and military advisers, and the servicemen who flew the planes that bombed Tripoli. In addition, in the wake of the war of Kosovo, many NGOs were calling for the Yugoslav War Crimes Tribunal to investigate the United States and NATO allies for their bombing campaigns. Even Milosevic brought a formal complaint that the NATO bombing constituted genocide. ${ }^{15}$

Governments defend their legitimate foreign policy and military decisions every day. Governments can handle it. Forcing individuals not only to articulate government policy, but potentially to stand trial for such policies would introduce a new dynamic into national decisionmaking. For some, injecting such a treaty into decisionmaking is precisely the goal.

An additional issue related to international courts is who controls the selection of the process to be pursued. For example, what happens when a country has a functioning legal system yet decides to move forward with a reconciliation process and not a judicial process? The pressure on the ICC, if established, to override such a decision by a country in the face of calls to do so from ICC parties will be tremendous. ${ }^{16}$

Finally, suppose such a court existed and spent the next twenty years dealing with cases from Eastern Europe, Africa, Asia, and perhaps South America. It is undoubtedly true that the court will be accused of a biased standard of justice that holds the United States and Europe to a different standard. The political pressure to show some mistaken sense of "evenhandedness" would be enormous, whether or not the international court has any legitimate basis for jurisdiction.

IV

\section{INSTITUTIONAL PROBLEMS}

The two existing international war crimes tribunals for the former Yugoslavia and for Rwanda have been in existence now for more than four years. The International Criminal Tribunal for the Former Yugoslavia was created by the U.N. Security Council in May 1993. The International Criminal Tribunal for Rwanda was created by the Security Council in November 1994. The tribunals have completed trials on a total of sixteen (including two who plead guilty) in the Yugoslav Tribunal and eight (including three who plead guilty) in the

15. See World Court Rejects Claims by Belgrade, TORONTO STAR, June 3, 1999.

16. Interestingly, the legal decision by Britain's law Lords holding it had jurisdiction to consider the extradition request by Spain for Chilean dictator Augusto Pinochet probably would be impossible in the United States. The shared understanding of the Senate and the Executive branch at the time of ratification of the Torture Convention, is that the treaty is "non-self executing." Therefore, the basis for extradition would have to be a violation of a criminal statute that exists in both the United States and Spain. Assuming no sovereign immunity was found, the fact the alleged criminal actions occurred neither in Spain nor the United States leaves it difficult to conceive a basis for extradition in the United States. 
Rwanda Tribunal. ${ }^{17}$ The U.N.'s Inspector General has produced two reports critical of the Rwanda Tribunal. The reports detail waste and managerial problems, as well as insufficient work loads by judges. The first report led the U.N. Secretary General to fire senior personnel, including the court's registrar. The second report noted some improvements under the new registrar, but continued to be critical of the court's management.

The location of such tribunals also remains unsettled. The response from the officials in Arusha, Tanzania-the Rwanda court's home-appears to be toward establishing a permanent facility. Ironically, the U.S. War Crimes Adviser, Ambassador David Scheffer, has discussed in staff-level briefings on Capitol Hill the merits of holding some of the trials in Rwanda. By doing so, he argues, the goal of bringing justice and closure to the massacres could be more tangible to the people of Rwanda. ${ }^{18}$ At the same time, during negotiations, the international humanitarian community was pushing governments to establish the ICC in The Hague, a location unlikely to facilitate meaningful participation in the judicial process by affected people.

Proponents of the tribunals like to compare them to the Nuremberg Tribunal. That comparison, however, raises many questions about the efficacy of the current tribunals. The Nuremberg Tribunal tried twenty-two individuals and six organizations. It began its work on November 20, 1945 and ended its work on October 1, 1946. Hearings were held on 218 days. The swift justice of this tribunal was a key factor in enabling war-torn Germany and the Allies to begin the reconciliation process.

A permanent tribunal brings with it permanent costs and a need to justify its existence. Some have suggested that there will be a skeletal staff in the instances when there is no work for the ICC. This is highly unlikely. No international-or federal, for that matter-organization has decreased its size or mandate without being forced to sunset or make drastic cuts. Some official is always finding more to do, and this will be the particular case for an organization that sees itself as the arbiter of international justice.

During the last five years, the financial burden of the tribunals has continued to increase. In his Fiscal Year 2000 budget, the President is requesting \$58 million to fund the United States's twenty-five percent share of the two tribunals. In Fiscal Year 1997, the United States spent about $\$ 15$ million on the tribunals.

17. See <http://www.un.org/icty/glance/keyfig-e.htm> (Yugoslav tribunal) and <http://www.ictr. org/> (Rwanda tribunal).

18. Staff briefing before the Senate Comm. on Foreign Relations (Dec. 16, 1998) (remarks of Ambassador David Scheffer). 


\section{LEGISLATIVE REACTION}

The Rome Treaty therefore, from the standpoint of many in the Senate, including the Chairman of the Senate Foreign Relations Committee, Senator Jesse Helms of North Carolina, is "fatally flawed." That is why the Chairman stated during a hearing last July that not only would he oppose the Treaty, but he would actively work to isolate an international criminal court. ${ }^{19}$

Chairman Helms announced he would seek assurances from the Secretary of State on the following points:

(1) The United States will never vote in favor of the Security Council referring a case to the ICC under Article 13(b).

(2) The United States will not provide any assistance to the ICC - or to any other international organization in support of the ICC-either in funding, in-kind contributions, or other legal assistance.

(3) The United States will not extradite any individual to the ICC, or directly or indirectly refer a case to it.

(4) The United States will include in all of its bilateral extradition treaties a provision that prohibits a treaty partner from extraditing U.S. citizens to the ICC.

(5) The United States will renegotiate all of its status of forces agreements to include a provision that prohibits a treaty partner from extraditing U.S. soldiers to the ICC, and will not station American forces in any country that refuses to accept such a prohibition.

(6) The United States will not permit a U.S. soldier to participate in any NATO, U.N., or other international peacekeeping mission until the United States has reached agreement with all of our NATO allies, and the U.N., that no U.S. soldier will be subject to the ICC's jurisdiction.

During the last Congress, the Senate started down the path of ensuring these protections. Contained in the resolutions of ratification of the more than thirty extradition and mutual legal assistance treaties approved by the Senate is a prohibition on bilateral partners sharing information or extradited individuals with the ICC. The Congress continued to solidify these protections in the James W. Nance and Meg Donovan Foreign Relations Act. ${ }^{21}$ The bill limits U.S. assistance to the ICC Tribunal unless the United States becomes a party to the Treaty by and with the advice and consent of the Senate.

In addition, on June 14, 2000, the Chairmen of the Senate Foreign Relations, Armed Services, Judiciary, and Intelligence Committees, as well as the majority leader of the Senate, introduced legislation that would address many of these issues. A similar companion bill was introduced in the House of Rep-

19. Hearing on the United Nationals International Criminal Court before the Subcomm. on Int'l Operations of the Senate Commission on Foreign Relatins, 105th Cong. (1998) (statement of Sen. Jesse Helms).

20. $I d$.

21. Pub. L. No. 106-113, fiscal years 200-2001. 
resentatives. The bill restricts U.S. engagement with the court unless the United States is a party to the treaty establishing the court. ${ }^{22}$

VI

\section{CONCLUSION}

Some argue that opposition to the ICC signifies a failure to care about the rule of law or international human rights. This is simply not the case. The United States with full congressional support will continue to stand for the rule of law and advance these standards globally.

In fact, many in Congress who oppose the court are also some of the stronger advocates of the United States speaking out against human rights abuses around the world. Rather than advocating the creation of an international criminal court, however, they argue that more should be done to facilitate extradition of criminals to stand trial where they are accused and to ensure there are no safe-havens for criminals. They also argue that more should be done to encourage functioning judicial systems, democratic elections, and less corrupt domestic institutions in every country.

These members of Congress have argued that supplanting failed domestic judicial systems with international courts is not a solution. However, the court proposed by the Rome Treaty, purposefully, one must suppose, is called an "international criminal court," not a war crimes tribunal. The goal of many of its supporters is broad-based international criminal jurisdiction, particularly to enforce human rights treaties that are aspirational and contain broad provisions that the United States may interpret very differently than other potential parties to the Rome Treaty.

Although the jury is still out on the success of the ad hoc tribunals, they do reflect political will to address the most serious crimes with the full backing of the international community. Requiring the Security Council's consent prior proceeding with judicial action ensures that governments are fully prepared to support and facilitate the court's activities.

The International Criminal Court attempts to take this decisionmaking authority away from governments and instill it more directly in a limited number of bureaucrats. Such a system cannot be beneficial to the long-term advancement of rule of law, and the establishment of local institutions directly accountable to the people they are designed to assist.

22. See S. 2726, The American Servicemembers' Protection Act of 2000. 